\title{
EXPLORING THE IMPACT OF HIGH PERFORMANCE WORK SYSTEMS IN PROFESSIONAL SERVICE FIRMS: A PRACTICES-RESOURCES-USES- PERFORMANCE APPROACH
}

\author{
$\mathrm{Na} \mathrm{Fu}$ \\ Leadership, Innovation and Knowledge (LInK) Research Centre, DCU Business \\ School, Dublin City University
}

This article aims to explore how a system of human resource management (HRM) practices influence firm performance in a professional service context. It integrates multidisciplinary theory and research findings. The system of HRM practices are labeled as high performance work systems (HPWS). In this article, it is proposed that HPWS influence firm performance through two steps: (1) by creating resources of human, social and organizational capital; and (2) by efficient uses of these resources. It indicates that firms using higher level of HPWS will experience better performance. The underlying mechanism is that HPWS first promote employees' ability, relationships, and opportunities; that is, the resources. These resources then facilitate the uses process, which is represented by 4 means: (1) sensing the changes in the external environment; (2) team formation and utilization; (3) leveraging knowledge from seniors to juniors; and (4) combining and exchanging knowledge. Uses finally lead to higher organizational performance. This approach is called the practices-resources-uses-performance linkage model. Employing this linkage process tool, managers are able to diagnose the requirements for organizational development. They can effectively adopt and implement HPWS. This article introduces a novel perspective for investigating the underlying mediating mechanisms that explain the link between HPWS and Professional Service Firm (PSF) performance.

Keywords: high performance work systems, professional service firms, linkages

Dr. Na Fu, Irish Research Council Postdoctoral Research Fellow, Dublin City University, Ireland.

Dr. Fu's research involves human resource management and knowledge management in professional service firms and public sector. The author would like to thank Patrick Flood, Janine Bosak, Denise Rousseau, and Tim Morris for their inspiration. The author is grateful for the helpful and constructive comments and suggestions of the Editor Robert B. Kaiser and other two anonymous reviewers throughout the reviewing process.

Correspondence concerning this article should be addressed to Dr. Na Fu, DCU Business School, Dublin City University, Glasnevin, Dublin 9, Ireland. E-mail: na.fu@dcu.ie 


\section{Background}

Professional Service Firms (PSFs) consist of highly educated and professionalized workforces that provide clients with customized knowledge (Empson, 2007; Greenwood, Li, Prakash, \& Deephouse, 2005; Maister, 1993). Examples of professional services include accounting, management consulting, and legal services.

PSFs differ from traditional manufacturing firms (Løwendahl, 2000). PSFs are knowledgeintensive (Anand, Gardner, \& Morris, 2007; Morris, 2001; Von Nordenflycht, 2007, 2010). Their inputs are mainly the knowledge possessed by the professional workforce (Starbuck, 1992), and their outputs are the expertise and knowledge in the form of customized solutions for clients (Empson, 2007; Greenwood et al., 2005; Hitt, Shimizu, Uhlenbruck, \& Bierman, 2006; Morris \& Empson, 1998).

To be successful, PSFs depend on three important resources. One is human capital; that is, the knowledge embedded in individuals (Becker, 1964; Wright \& McMahan, 2011). Human capital is built up through formal education and on-the-job training within PSFs (Hitt, Bierman, Shimizu, \& Kochhar, 2001). Most PSF employees are highly educated, recruited from universities. They also receive a lot of training in their daily work. Indeed, their continuing education requirements are often regulated by the professional association to which they belong. For example, to become a qualified chartered accountant in some jurisdictions, a trainee needs to have at least three and a half years' training in an accountancy practice (or 3 years for a master student).

Another resource is social capital; that is, the knowledge embedded in the relationships among individuals (Burt, 1992; Chuang, Chen, \& Chuang, 2013; Nahapiet \& Ghoshal, 1998; Truss \& Gill, 2009). Most of the work in PSFs is carried out through teams. Good relationships between team members facilitate the knowledge exchange and sharing process and therefore improve efficiency. Developing and maintaining the relationships with clients is also important for PSFs for two reasons: (1) the firm requires clients' input in the service; and (2) it attracts ongoing new business often by existing clients introducing the firm to new clients. The internal and external relationships are the most important sources for building up social capital.

The third resource is organizational capital; that is, the knowledge embedded in organizational processes, routines, databases, and systems (Subramaniam \& Youndt, 2005; Youndt, Subramaniam, \& Snell, 2004). Professionals play an important role in forming efficient organizational routines and building organizational databases and systems that facilitate knowledge exchange and sharing within firms. More details will be presented in the subsections.

To summarize, human resources constitute the most critical asset of PSFs. Therefore, an investigation should be conducted to ascertain what HRM practices will serve to build the resources of human, social, and organizational capital. In this article, high performance work systems (HPWS) are used to present a system of HRM practices. It is argued that HPWS create the resources (human, social, and organizational capital), and the efficient uses of these resources then create value for the firm and help it gain competitive advantages. This is the practices-resources-uses-performance linkage model proposed in this article. Professional service firms are an appropriate context to examine HPWS because human resources constitute the critical asset in PSFs and therefore permit a strong test of the practices-resources-uses-performance model.

The article is structured as follows. In the following section, it introduces the literature on HPWS. Two research arguments in the existing HPWS-firm performance research are analyzed as (1) the indirect link versus the direct link; and (2) the omitted context of PSFs. It then proposes a conceptual model that links HPWS and firm performance through two sets of mediators which are resources and uses. HPWS are argued to affect firm performance in PSFs through two steps: (1) HPWS create firm resources; that is, human, social, and organizational capital; and (2) these resources are used to improve firm performance through four means. These four means are sensing market changes, team formation and utilization, leveraging knowledge from seniors to juniors (shortened to leveraging knowledge), and combining and exchanging knowledge. These means help PSFs to achieve efficient exploitation in a short run and transformation and exploration in a longer run. Within the HPWS and firm performance relationship research, the model draws on the 
practices-resources-uses-performance perspective and provides important theoretical foundations for understanding how HPWS affect firm performance. Further implications of the study for practitioners are then discussed. The conceptual model is shown in Figure 1.

\section{Literature Review and Propositions}

A system or bundle of specific human resource (HR) practices have been found to be positively related to organizational performance. For example, HPWS have been found to positively relate to outcomes especially in manufacturing firms (e.g., Datta, Guthrie, \& Wright, 2005). These organizational outcomes investigated include financial performance (Guthrie, 2001; Huselid, 1995), employee turnover (Richard \& Johnson, 2001), firm productivity (Guthrie, 2001), efficiency and flexibility (Evans \& Davis, 2005), and organizational commitment (Youndt, Snell, Dean, \& Lepak, 1996).

More specifically, Youndt et al. (1996) demonstrate that a human capital-enhancing HR system has a direct positive relationship with multiple dimensions of a firm's operational performance, such as employee productivity, machine efficiency, and customer alignment. Collins and Clark (2003) indicate that network-building HR practices positively relate to organizational performance, that is, growth in sales and stock return. Huselid (1995) illustrates a positive relationship between high performance work practices and organizational turnover, productivity, and financial performance. The studies on HPWS conducted by Datta et al. (2005) and Guthrie, Flood, Liu, and MacCurtain (2009) find that HPWS positively affect firm's labor productivity, employee absenteeism, and employee turnover. The three meta-analyses by Combs, Liu, Hall, and Ketchen (2006); Jiang, Lepak, Hu, and Baer (2012); and Subramony (2009) all find that the HRM bundles are positively linked to firm performance. For example, HRM bundles or systems are positively related to firm performance, and they have larger effects ( $r=.28$, in Combs et al., 2006) than individual HRM practices ( $r=.14$, in Combs et al., 2006) on firm performance.

The existing research on the HPWS-firm performance link generates two lines of arguments. The first of these is that research has mostly focused on the direct link while neglecting the underlying mechanisms that explain this link; that is, the indirect link. The second is that the HPWS-firm performance link has been tested in general manufacturing firms while investigation had been lacking in professional service firms. PSFs' success highly depends on their human

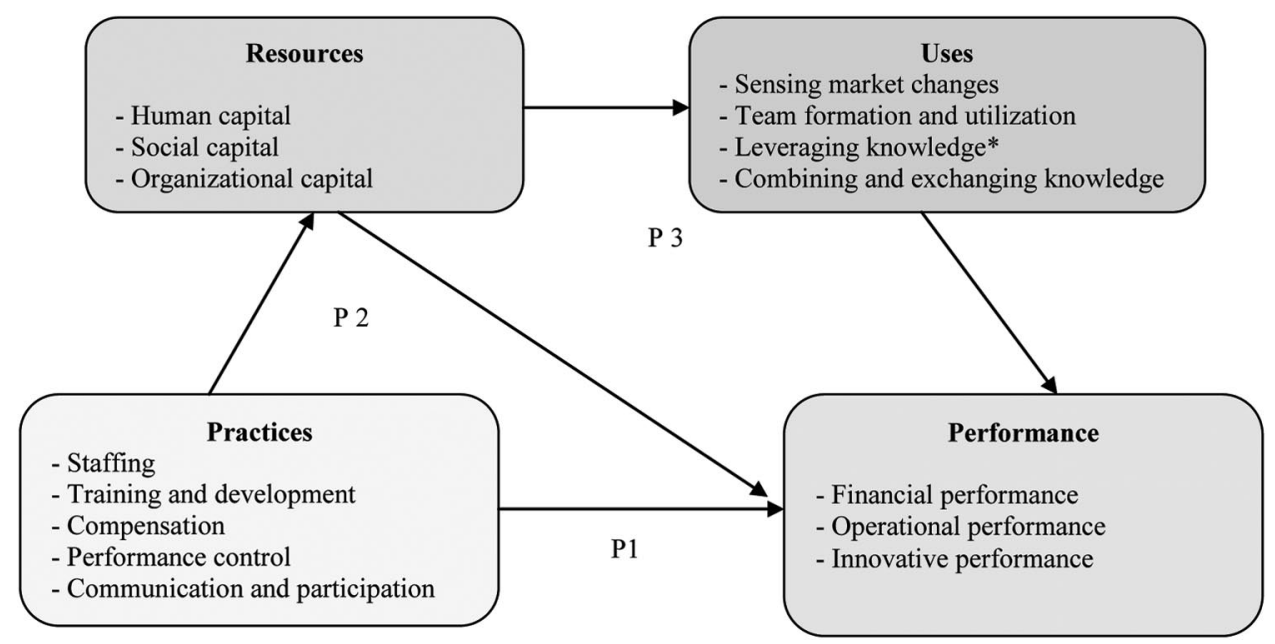

Figure 1. Conceptual Model with Relevant Propositions. Leveraging knowledge indicates leveraging knowledge from seniors to juniors. 
resource. They are therefore an appropriate and important context to investigate the performance impact of HPWS.

Regarding the first argument, HPWS might affect firm performance directly and also indirectly. Many scholars agree that moderators and mediators exist between HRM practices and firm performance. In a meta-analysis, findings by Combs et al. (2006) suggest that organizational strategy and context may moderate the relationship between HRM and firm performance. In one empirical study, Youndt et al. (1996) find that organizational manufacturing strategy, such as cost strategy, quality strategy, and flexibility strategy, moderates the HR practices and firm performance relationship. In another empirical study, Datta et al. (2005) investigate the moderating role of industry characteristics, such as industry capital intensity, industry growth, industry product differentiation, and industry dynamism. Their results demonstrate the potential for industry context to moderate the relationship between HR systems and organizational effectiveness. In a recent meta-analysis, Jiang et al. (2012) find that HR systems are both directly and indirectly related to organizational financial outcomes where the mediators are human capital and employee motivation. Combs et al. (2006) also suggest that employees' knowledge, skills, and abilities (KSAs) and the social structure act as mediators between high performance work practices and organizational performance. Guest (1997) shows that strategic HRM (SHRM) improves firm performance by enhancing employees' skills and abilities. Collins and Clark (2003) provide support for the mediating role of social structure. They examine the mediating effect of social networks of top management teams (TMTs) on the relationship between HRM and firm performance. They find that the mediating effects of TMT networks account for nearly all of the effects of network-building practices on sales growth and less than half of the effect of incentive pay practices based on organizational performance. In addition, Wright, Dunford, and Snell (2001) argue that HPWS might play a role in creating organizational cultures and shared organizational knowledge that enables the firm to form and maintain its core competitive advantages. They indicate that HR practices may help shape organizational processes, systems, and ultimately build organizational competences. Last, Fu, Flood, Bosak, Morris, and O'Regan (2013) find that team formation and utilization is one important mediator between HPWS and service supply chain performance.

The second argument arises because of the samples contexts used in the existing research. Many researchers conduct their research in general manufacturing firms, such as auto manufacturing plants, steel companies (e.g., Arthur, 1994; Datta et al., 2005; Ichniowski \& Shaw, 1999; Macduffie, 1995), general service firms such as banks (Delery \& Doty, 1996; Richard \& Johnson, 2001), or a mix of companies (Guthrie et al., 2009; Huselid, 1995). They omit another important contextprofessional service firms whose input and output come from knowledge embedded in their professional workforce. Therefore, their most important resources are human resources. PSFs gain competitive advantage mainly by relying on their intangible assets; that is, their expert knowledge, internal and external relationships and the efficient routines, and databases and systems, rather than on tangible physical assets. Therefore, the professional service context represents an ideal setting to examine the impact of HR practices on firm performance. Indeed, such firms play an important role in the global economy (Greenwood et al., 2005; HM Treasury, 2009).

Many scholars have called for deeper and more theoretical approaches to understand how and why HPWS affect firm performance (Bowen \& Ostroff, 2004; Combs et al., 2006; Delery \& Shaw, 2001; Jiang et al., 2012; Paauwe, Guest, \& Wright, 2013; Wright \& Gardner, 2000), especially in service organizations (Combs et al., 2006). In response, this article analyzes the mediating role of firm resources; that is, human, social, and organizational capital in the HPWS-firm performance relationship. In addition, it is argued that only when these resources are effectively managed and utilized can firms generate increased profit (Schultz, 1961), achieve sustainable competitive advantage, and create value (Barney \& Arikan, 2001; Sirmon, Hitt, \& Ireland, 2007).

Therefore, two research questions are pursued in this article:

(1) How do HPWS affect firm performance in the professional services context?

(2) What are the valuable resources for PSFs and how are they utilized by firms to help achieve high firm performance? 


\section{HPWS and Firm Performance}

The resource-based view of the firm (RBV) argues that a firm's competitive advantage lies primarily in the valuable, rare, imperfectly imitable, and nonsubstitutable (i.e., the VRIN criteria) resources that a firm already has (Barney, 1991; Penrose, 1959; Wernerfelt, 1984). "Valuable" indicates that the "resource must enable a firm to employ a value creating strategy by either outperforming its competitors or reducing its own weakness" (Barney, 1991: 99). "Rare" indicates that the resources should be by definition rare and not easily taken by every firm. "Imperfectly imitable" indicates that the resource cannot be easily imitated by other competitors. "Nonsubstitutable" indicates the resource owned by the firm should not be substitutable by other firms. Only the firms that have superior resources and protect them from diffusion throughout the whole industry can maintain sustainable competitive advantage and sustain high performance levels. These resources can be tangible or intangible. The intangible resources such as knowledge are more difficult to imitate and therefore are important for firms to maintain.

The knowledge-based theory of a firm considers the intangible resource of knowledge as the most strategically significant resource of the firm (Grant, 1996a, 1996b). This knowledge is embedded and carried through multiple entities including individuals, relationships and organizational processes, routines, databases, and systems.

Guided by the resource-based view of firm (Barney, 1991) and the knowledge-based theory of firm (Grant, 1996a, 1996b), this article defines HPWS as an integrated system of HR practices that enhance employees' knowledge and skills (Datta et al., 2005; Guest, 1997; Guthrie, 2001; Huselid, 1995), strengthen their internal and external relationships (Bowen \& Ostroff, 2004; Evans \& Davis, 2005), and also support organizational processes, routines, databases, and systems in such a way that the firm's resources are created to gain sustainable competitive advantage. HPWS include staffing, training and development, compensation, performance control, and communication and information sharing (Becker \& Huselid, 1998; Datta et al., 2005; Guest, 1997; Guthrie, 2001; Guthrie et al., 2009; Huselid, 1995). These practices are listed and explained in Table 1.

These practices represent the general HRM practices commonly used in most HPWS research, such as staffing, training and development, compensation, performance control, and communication and participation (e.g., Pfeffer, 1998). However, the subcomponents of HPWS are different from those that are used in the general context. For example, the performance control practice includes performance appraisals but also include monitoring trainees. In PSFs, many trainees are recruited each year and must become professionally accredited while they are trained on-the-job. They acquire formal knowledge through training and experience through the performance of day-to-day tasks. After qualification, many of them will choose to leave the firm but others will remain. They are usually self-motivated to acquire qualifications but monitoring and coaching is often necessary. Efficient monitoring practices could help PSFs reduce costs and improve firm performance. Therefore, because of the distinctiveness of PSFs, monitoring practice is added into the HPWS.

Based on the existing research in PSFs, firm performance could be defined as financial performance, such as the turnover (Nachum, 1999) and profit per partner (Pinnington \& Morris, 2003); operational performance, such as productivity measured by revenue per professional (Greenwood, Deephouse, \& Li, 2007; Greenwood et al., 2005); and innovative performance, such as the number of creativity awards won in a given year (Von Nordenflycht, 2007) and self-reported innovation scales (Hogan, McColl-Kennedy, Soutar, \& Sweeney, 2008; Subramaniam \& Youndt, 2005).

In addition to the main theme of HPWS-firm performance link, this article suggests that HPWS is positively related to PSF performance, such as financial returns, productivity, and innovation:

Proposition 1: A PSF's investments in HPWS are positively related to its financial, operational, and innovative outcomes.

\section{HPWS and Resources}

There is a positive relationship between HPWS and firm performance, but how HPWS affect firm performance is not well understood. 
Table 1

Categories of Human Resource Practices Comprising High Performance Work Systems (HPWS)

\begin{tabular}{|c|c|c|}
\hline $\begin{array}{l}\text { Human Resources } \\
\text { Practice Category }\end{array}$ & Description & Examples \\
\hline Staffing & $\begin{array}{l}\text { Extensiveness of procedures to } \\
\text { evaluate relevant knowledge, skills, } \\
\text { and abilities for job fit and } \\
\text { organization fit. }\end{array}$ & $\begin{array}{l}\text { Selective screening through multiple } \\
\text { sources. } \\
\text { Assessment of technical and } \\
\text { interpersonal skills, attitudes, and } \\
\text { personality. } \\
\text { Performance-based or seniority- } \\
\text { based promotions. }\end{array}$ \\
\hline $\begin{array}{l}\text { Training and } \\
\text { development }\end{array}$ & $\begin{array}{l}\text { Extensiveness of formalized programs: } \\
\text { to develop employees' professional } \\
\text { and firm-specific knowledge, } \\
\text { management skills, and } \\
\text { communication abilities, and team } \\
\text { working abilities;. }\end{array}$ & $\begin{array}{l}\text { Training for current and future } \\
\text { skills, including technical and } \\
\text { interpersonal. }\end{array}$ \\
\hline & $\begin{array}{l}\text { Provide opportunities to employees to } \\
\text { attend external studies. }\end{array}$ & $\begin{array}{l}\text { Cross-training. } \\
\text { Training for both new hires and } \\
\text { experienced employees. } \\
\text { Provide employees opportunities for } \\
\text { attending external conferences } \\
\text { and seminars. }\end{array}$ \\
\hline Compensation & $\begin{array}{l}\text { Performance-contingent pay. } \\
\text { Group-based pay. } \\
\text { Above-market pay policies. } \\
\text { Encourage employees to develop } \\
\quad \text { external relationships. }\end{array}$ & $\begin{array}{l}\text { Profit/gain sharing. } \\
\text { Employee ownership. } \\
\text { Comparatively high level of pay. } \\
\text { Performance-contingent pay. } \\
\text { Team-based pay. } \\
\text { Reimburse employees for } \\
\text { developing networks with } \\
\text { potential and existing clients. }\end{array}$ \\
\hline Performance control & $\begin{array}{l}\text { Improve performance by giving } \\
\text { employees' feedback. } \\
\text { Encourage employees to embrace } \\
\text { errors in exploring new knowledge. }\end{array}$ & $\begin{array}{l}\text { Performance appraisals from } \\
\text { multiple sources. } \\
\text { Informal monitoring reports. }\end{array}$ \\
\hline $\begin{array}{l}\text { Communication and } \\
\text { participation }\end{array}$ & $\begin{array}{l}\text { Open vertical and horizontal } \\
\text { communication channels providing } \\
\text { access to information and } \\
\text { opportunities to express viewpoints. }\end{array}$ & $\begin{array}{l}\text { Access to all levels of operating } \\
\text { results. }\end{array}$ \\
\hline & $\begin{array}{l}\text { Encourage transference of tasks and } \\
\text { responsibilities to employees. }\end{array}$ & $\begin{array}{l}\text { Employee suggestion systems. } \\
\text { Explanation of business strategy. } \\
\text { Reduction of status barriers between } \\
\text { managers and employees. }\end{array}$ \\
\hline
\end{tabular}

Note. Based on Evans and Davis, 2005; Guthrie et al., 2009; and Kang and Snell, 2009.

This article argues that HPWS affect firm performance by creating valuable, rare, imperfectly imitable, and nonsubstitutable resources (Barney, 1991); that is, human, social, and organizational capital. These resources can also be understood as the knowledge that embedded in individuals, relationships among individuals and the organizational routines, database, and systems.

Human capital. Human capital refers to the stock of skills and knowledge embodied in individuals (Becker, 1964; O’Sullivan \& Sheffrin, 1998; Wright \& McMahan, 2011), which can be achieved through education and training (Becker, 1964).

Some scholars have found that HPWS affect firm performance through improving employees' human capital. For example, Guest (1997) indicates that SHRM improves firm performance by 
enhancing employees' skills and abilities. Snell and Dean (1992) argue that HRM practices affect a firm's financial performance by creating higher human capital skills, experience, and knowledge. Wright et al. (2001) assert that HPWS facilitate in building a firm's competitive advantage by creating a high-quality human capital pool that is not easily imitated by its competitor in a given time frame. Becker and Huselid (1998) explain that human resource activities contribute to a firm's competitive advantages by developing employees' skills. They argue that a highly skilled workforce will help the firm to achieve higher financial performance.

In PSFs, human capital is defined as the knowledge embedded in professionals that can be used to produce high quality professional services for clients (Hitt et al., 2001; Hitt et al., 2006; Pennings, Lee, \& Van Witteloostuijn, 1998).

Human capital is a very important asset of PSFs (Hitt et al., 2001; Morris \& Snell, 2008). Higher human capital in a PSF is represented by increased expertise and knowledge embedded in highly professionalized workforce. It helps PSFs build a good reputation by signaling that the professional service firm has the potential to provide more efficient solutions for its clients. Clients are likely to choose PSFs with higher level human capital because they believe that smarter people would provide better solutions ceteris paribus. PSFs achieve high human capital through recruiting graduates from top institutions because they potentially have better learning capability. In addition, extensive training programs can help to build human capital as most people want to learn more and are interested in opportunities that develop personal skills. Higher level human capital also helps PSFs to attract more talent and brighter graduates from top institutions.

To build high levels of human capital, PSFs need to identify, attract, and retain superior professionals. This can be achieved through HR practices such as selection, recruitment, training, and skill-based pay. Thus, this article suggests that HPWS affect firm performance through improving PSFs' human capital.

Social capital. Social capital is a resource that is embedded in the relationships among individuals (Bourdieu, 1985; Burt, 1992; Coleman, 1988; Lin, 2001; Nahapiet \& Ghoshal, 1998; Putnam, 1993).

HRM practices can play a significant role in creating social capital. For example, Wright et al. (2001) argue that HPWS affect firm performance in many different ways and give one example that “... these [human resource management] systems may promote and maintain socially complex relationships characterized by trust, knowledge sharing, and teamwork” (p. 710). Leana and Van Buren III (1999) find that employment practices foster organizational internal social capital and that organizational social capital creates value for firms. In other words, organizational social capital mediates the HRM practices and organizational performance relationship. Evans and Davis (2005) analyze the mediating role of the social structure between HPWS and organizational performance. They propose that HPWS improve organizational financial efficiency and organizational flexibility through their impact on organizational social structure development. Chuang et al. (2013) finds support for the link between HRM practices and organizational social capital. Truss and Jill (2009) find support for the important role of social capital in predicting HR functional performance for both HR staff and line managers.

As described in the previous section, social capital has two sources: internal, coworker relationships and external relationships with clients. In PSFs, social capital has two corresponding functions. First, the capital embedded in the internal relationships among professionals within the firm could help PSFs deploy teams, coordinate tasks and communicate within the firm efficiently. Second, the social capital based on the relationship between staff and clients helps PSFs to attract and retain clients. The service delivered by PSFs suffers from an "opaque quality" (Von Nordenflycht, 2010), mainly because the PSFs inputs and outputs are intangible knowledge and it is difficult for the clients to evaluate the quality of service that they will get or have received. When choosing a service provider, clients usually choose the ones who have relationships with them when other things are equal (Alvesson, 2001; Pennings et al., 1998). Pennings et al. (1998) defined firms' social capital as the ties that exist between the firms' professionals and potential clients. They found that a firm's human and social capital has a great 
influence on firm dissolution in law firms. Their study shows that firm-level human and social capital could be important sources of competitive advantage.

In this article, PSFs' social capital is defined as the knowledge embedded in the relationships among professionals and between professionals and clients. Some HR practices contribute to building social capital through training, compensation, and communication and information sharing practices. For example, to build internal social capital, PSFs can provide training programs to improve professionals' teamwork and communication skills, compensation policies such as groupbased pay and bonus sharing plan and open vertical and horizontal communication channels for professionals sharing and exchanging knowledge within the firm though the use of employee suggestion systems. To build external social capital, PSFs can provide professionals with external training opportunities and reimburse them for developing networks with potential and existing clients.

Therefore, the mediating effect of social capital is expected in the HPWS-firm performance link in PSFs.

Organizational capital. Organizational capital is defined as the institutionalized knowledge residing within organizational processes, routines, systems and structures (Subramaniam \& Youndt, 2005; Youndt, Subramaniam, \& Snell, 2004) and is the result of integrating and combining individual knowledge into organizational knowledge (Grant, 1996a, 1996b) and is preserved over time (Daft \& Weick, 1984). Organizational capital is a source of organizational competitive advantage (Teece, 2000).

Some scholars propose that HR practices affect firm performance through building organizational capital. For example, Ferris et al. (1998) point out that HR practices affect organizational effectiveness by shaping organizational work climate. According to Kopelman, Brief, and Guzzo's (2005) definition, work climate can be understood as the extent to which management know the organizational processes, databases, and systems that employees could use to accomplish their work. In addition, Wright et al. (2001) argue that HPWS might play a role in creating organizational cultures and shared organizational knowledge that enables firms to form and maintain its core competencies. Their work indicates that HR practices may affect firm performance by forming organizational processes and systems.

In PSFs, organizational processes are highly institutionalized due to the nature of knowledgebased work (Freidson, 1986; Greenwood, Hinings, \& Brown, 1990; Robertson, Scarbrough, \& Swan, 2003). The organizational routines in PSFs are often informal work practices that are formed by professionals during their team work (Morris, 2001). Some large PSFs build their own databases and systems that store individual experience and expert knowledge (Suddaby \& Greenwood, 2005). They are also called knowledge centers (Moore \& Birkinshaw, 1998). These databases and systems provide support for professionals to reuse and exploit existing knowledge. Most PSFs have flat organizational structures (Greenwood et al., 1990; Stumpf, Doh, \& Clark, 2002) that facilitate knowledge flow between seniors and juniors.

Organizational capital constitutes an important resource for PSFs by facilitating knowledge creation, sharing, combination and exchange (Morris \& Snell, 2008). Besides facilitating knowledge integration, organizational capital also shapes professionals' image and identity (Empson, 2001) which play an important role in attracting new clients.

HPWS contribute to building organizational capital in PSFs through staffing, training and performance control (Kang \& Snell, 2009; Youndt et al., 2004). In practice, when recruiting new people, the fit between candidates' attitudes and organizational culture need to be considered also called person-organization fit. During the training process, not only the professional knowledge but also the organizational databases and systems and the firm's shared values need to be introduced to employees. In performance control, the errors could be embraced to encourage employees to explore new knowledge in order to form an organic organizational capital (Kang \& Snell, 2009).

Based on the above analysis of human, social and organizational capital in PSFs, the mediating role of resources in the HPWS and firm performance link is proposed as follows. 
Proposition 2: A PSF's "resources" mediate the relationship between HPWS and firm performance.

\section{Uses of Resources}

The RBV and the knowledge-based theory of the firm contribute to identifying the existing resources that have the potential to constitute a source of sustainable competitive advantage for organizations (Hitt et al., 2006). These valuable resources must be effectively managed and utilized to achieve a superior profit (Schultz, 1961) and a competitive advantage (Sirmon et al., 2007). The emphasis on the use of resources is consistent with the dynamic capabilities perspective (Teece, Pisano, \& Shuen, 1997), which emphasizes how to develop, integrate, and leverage these resources within the firm.

Using these resources means using the knowledge embedded in individuals, relationships and organizational processes, routines, databases, and systems. There are three main means to utilize knowledge (Lichtenthaler, 2009, March, 1991). One focuses on how to reuse or replicate existing knowledge; that is, exploitation. The second one focuses on how to generate new knowledge, that is, exploration. The third one, transformation, links exploration and exploitation by maintaining and reactivating knowledge. All three use mechanisms are highly reliant on the knowledge, skills and abilities of professional staff, as well as their willingness and motivation to do so (Wasko \& Faraj, 2005). Therefore, the resources of human, social, and organizational capital play an important role in facilitating them. The effective use of resources may help a PSF to balance the effective exploitation of existing resources, exploration of knowledge to create new capabilities, with transformation from exploration to exploitation. The matrix shown in Figure 2 demonstrates how PSFs create value by exploiting, transforming, and exploring resources.

The matrix shows that the exploration of resources in PSFs serves to deliver new products or services to new clients. The exploitation of resources in PSFs serves to deliver existing services or products to the existing clients. The transformation of resources serves to deliver new products or service to existing clients and to deliver existing services to new clients. For the

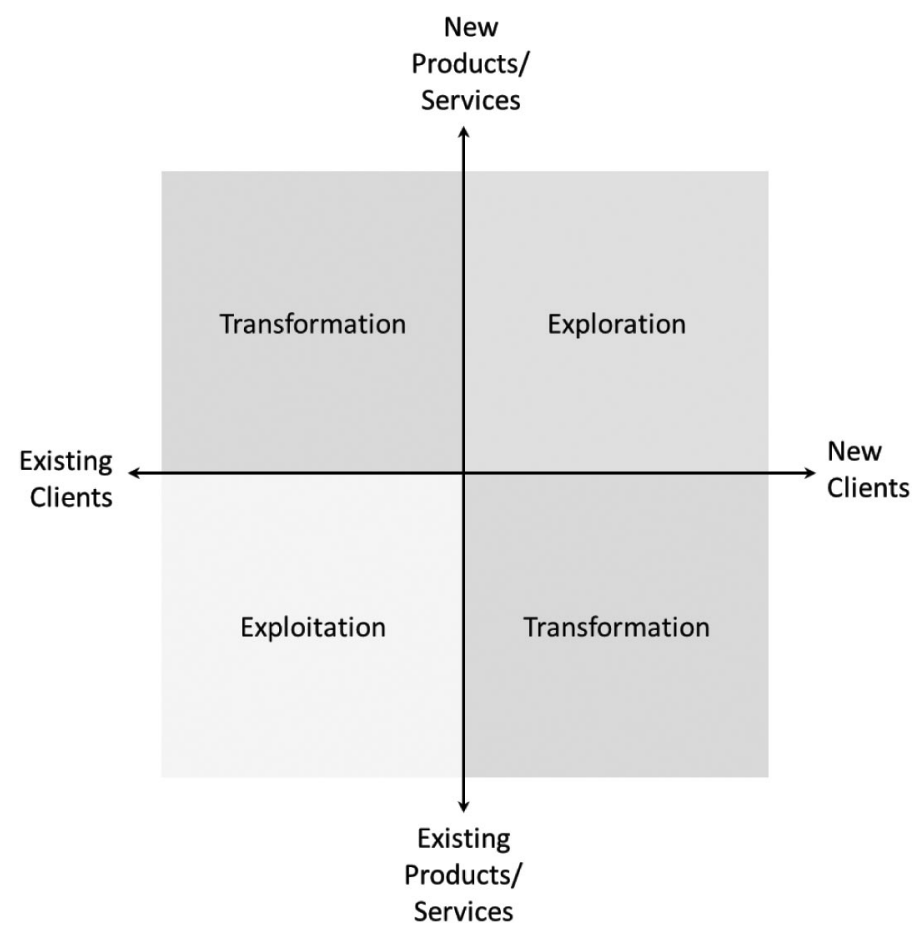

Figure 2. The exploitation, transformation, and exploration in Professional Service Firms (PSFs). 
exploration process, human capital is required to invent new products or services. Social capital is used to attract new clients and new business. The organic organizational capital (Kang \& Snell, 2009) has an important role in facilitating this delivery. Organic organizational capital indicates that the organizational system is willing to embrace errors. It encourages employees to participate in problem-solving and decision-making. The exploitation process needs to reuse or refine the existing products or services to existing clients. The standardized organizational capital (Kang \& Snell, 2009 ) is required to facilitate this delivery. The opposite of the organic organizational capital is the standardized organizational capital where the organizational systems avoid errors. For the transformation process, it involves providing new services to existing clients and to invent these new services, human capital is needed. It also involves providing existing services to new clients and this requires social capital to attract these clients. Similar to exploration and exploitation, organizational capital will facilitate this process.

To illustrate exploration, transformation, and exploitation in more detail, four ways of using PSFs' resources of human, social and organizational capital are identified. They are as follows: "sensing market changes," "team formation and utilization," "leveraging knowledge (i.e., leveraging tacit knowledge from seniors to juniors)," and "combining and exchanging knowledge." These four approaches are needed in the exploitation of existing resources, exploration of knowledge to create new capabilities, and transformation between exploration and exploitation.

Sensing market changes. PSFs need to use their resources to develop the products or service required by new markets and to attract new clients. Before this, PSFs need to understand the market dynamics in their environment. In this article, these capabilities of PSFs are defined as sensing the changes in the external market. Environmental sensing capabilities allow PSFs to find and build relationships with new clients and to generate new products and/or services for new markets. For example, when private equity (PE) firms came into prominence in the market, some PSFs developed a dedicated PE practice to attract PE firms. PE refers to companies that are privately held by owners and their activity tends to coincide with corporate merger and acquisition activities (Morris, Gardner, \& Anand, 2007). Another example is the new redundancy service introduced by Deloitte at the early stage of the global crisis (www.deloitte.com/ie/evolve). To help the organizations review their internal management, the professionals in Deloitte formed an "Evolve to Succeed" team, which comprises people from different departments; for example, the human capital, employment tax, and pensions and investment departments, and providing redundancy plan services.

To build up the capability of sensing changes in the external environment, professional staff within PSFs are required to spend more time generating future business through using their social capital. They are also required to exploit and explore their human capital to generate new products or services to meet clients' needs. During these processes, organizational capital has an important role in encouraging people to get involved in innovation. As argued by Ireland, Hitt, and Sirmon (2003), the people with higher human capitals are more likely to make sense of opportunities. They then need to communicate the value of such opportunities and exploit them in order to contribute to the firm's overall goals.

Team formation and utilization. In professional service firms, most of the work is project or program-oriented. To meet client's needs, a partner needs to choose several professionals to form a team which has the capacity to solve their client's requests. The team forms the basic unit of work in the professional service firm. PSFs are required to deploy teams and coordinate tasks efficiently due to the fast economic development. The dynamic global economic environment accelerates the speed at which PSFs' need to work. Usually, the customers' assignments are compressed in term of time (Morris et al., 2007). As a result, PSFs have to compress their work into a much shorter time frame. As in Morris et al.'s (2007) study, a partner from a consulting firm said "... [we need to] compress six months work into a three week assignment."

Because professionals usually need to work together rather than independently, effective communication among them is a prerequisite to accomplish the work. They need to exchange opinions and to create solutions through teamwork to meet their clients' needs. Efficient team formation and utilization is therefore a key factor for PSFs' success. This means that the PSFs can 
form a team quickly based on knowing each other's expertise and they can utilize these teams effectively in encouraging knowledge exchange and combination. This will contribute to improving the efficiency of the firm's human capital and social capital while they are creating new knowledge. In an empirical study by Newell, Tansley, and Huang (2004), social capital was found to be critical for knowledge integration within teams. To successfully complete projects, selecting project team members with appropriate knowledge, skills and expertise (human capital) is imperative. It is unlikely that project team members have all the relevant knowledge and expertise necessary for the project. Rather, these project team members need to network with others. Therefore, social and organizational capital facilitates the knowledge integration and new knowledge creation process, which leads to the successful delivery of customized solutions to clients.

Leveraging knowledge. Leveraging knowledge is the transfer of tacit knowledge from seniors to juniors in client assignments (Hitt et al., 2001). As stated by Hitt et al. (2001), "[b]uilding associates' knowledge necessitates that partners leverage their own knowledge, particularly their tacit knowledge" through face-to-face interactions (p.15). In PSFs, partners have the most vested interests in human and social capital (Hitt et al., 2001; Pennings et al., 1998). To meet clients' demands, partners need to select other professionals to form a team that possesses the required knowledge, skills, and experience. In this way, the partners' tacit knowledge can be transferred to other junior employees or associates; that is, leveraging knowledge. According to Greenwood et al. (2005) and Hitt et al. (2001), PSFs compete with each other by leveraging knowledge between senior and junior employees.

Leverage ratios are measured by the total number of associates divided by the total number of partners (Hitt et al., 2001; Phillips, 2001). From the knowledge perspective, high leverage ratios mean that more codified and explicit knowledge is imputed by junior professionals. Lower leverage means high professionalized expertise knowledge is imputed by more senior ones (Hansen, Nohria, \& Tierney, 1999; Maister, 1993). A high leverage ratio indicates that the firm focuses more on exploiting existing knowledge while a low leverage ratio indicates that the firm focuses more on exploring new knowledge.

Effective leverage of the knowledge embedded in partners and associates helps PSFs to balance the exploration, transformation and exploitation of knowledge in order to meet existing and new clients' needs (Hitt et al., 2001; Teece et al., 1997). Hitt et al. (2001) found empirical support for the positive effect of leveraging knowledge on firm performance in the professional service context.

Combining and exchanging knowledge. Combining and exchanging knowledge allows the possibility of knowledge flow between individuals and within organizations. This ability helps PSFs to create new knowledge which enables them to innovate and to gain competitive advantages (Collins \& Smith, 2006; Grant, 1996a). Nahapiet and Ghoshal (1998) suggest that the social capital generated from the relationships among individuals drives knowledge exchange and combination processes. Collins and Smith (2006) also find support for the idea that organizational social climate conditions facilitate knowledge exchange and combination and result in higher firm performance.

To summarize, PSFs use their resources through sensing the changes in the external environment, team formation and utilization, leveraging knowledge from seniors to juniors, and by combining and exchanging knowledge.

These arguments lead to the following proposition.

Proposition 3: The PSFs' "uses" mediate the relationship between resources and performance.

\section{Discussion}

In this article, a new perspective is introduced to examine the underlying mediating mechanisms that explain the link between HPWS and PSF performance. The "practices-resources-uses-performance" approach looks at two sets of potential mediators; that is, resources and uses, which explain how HPWS affect firm performance. By doing so, this article has important implications for theory and practice. Below, these implications are discussed. 


\section{Implications for Organization and Strategic Theories}

This study developed a framework of practices-resource-uses-performance in identifying a systematic pathway through which HPWS affect firm performance. Two sets of mediators were identified between HPWS and firm performance. The first set of mediators was the resources of human, social, and organizational capital. The second set of mediators was the uses of the above resources, which are: sensing the changes in the external environment, team formation and utilization, leveraging knowledge from seniors to juniors, and the combining and exchanging knowledge.

A major contribution of this article is adding organizational capital to human and social capital to predict firm performance. Previous research into mediators between HPWS were confined to either investigating only one or two possible mediators out of three. For example, Collins and Smith (2006) examined the mediating effect of social networks in top management teams on the HRM and firm performance link. Gittell, Seidner, and Wimbush (2010) examined the mediating role of relational coordination, which concerns shared goals and mutual respect in the HPWS and organizational performance relationship. Takeuchi, Lepak, Wang, and Takeuchi (2007) examined the mediating roles of human capital and social exchange between HPWS and organizational performance. An added contribution of this article to existing research is the inclusion of human and social capital along with organizational capital as an additional mediator to exampling the relationship between HPWS and firm performance. Identifying new mediators will help to explain more variance and therefore provide a much clearer understanding of the mechanism through which HPWS influence firm performance. As noted by Richard and Thompson (1999) "how something is done is often more important than what is done" but the empirical studies focus on the latter in the realm of HRM research.

This article also adds to the literature in a novel by adding an additional set of mediators, uses, through which the resources of human, social, and organizational capital can affect firm performance. In doing so, it also highlights the mediating role of uses in the relationship between resources and firm performance. Of the existing research on human, social and organizational capital, many researchers have only examined the direct link between resources and organizational performance. For example, Youndt et al. (2004) examined the effect of human, social, and organizational capital on firms' performance. Subramaniam and Youndt (2005) examined the effect of human, social, and organizational capital on two types of innovation capabilities in high technology firms. Others have focused solely on one or two forms of capital. For example, Pennings et al. (1998) examined the effect of human and social capital on firm dissolution in PSFs. Hitt et al. (2006) examined the effect of human capital and social capital on the internationalization of PSFs and the focus was specifically on law firms. The propositions formed in this study indicate the significant direct effects of human, social, and organizational capital on firm performance. This is consistent with previous research conducted in different organizational contexts. Moreover, the article analyses and proposes the uses as one important mechanism underlying the resource and performance link. By doing so, the present study integrates the resources-based view of the firm, knowledge-based theory and dynamic capabilities theory. It provides further insights and further highlights the importance of utilizing resources to create value for firms (Sirmon et al., 2007).

A third contribution of this article is the specific context being analyzed-PSFs. Most of the previous literature on the relationship between HR systems and firm performance has included contexts such as manufacturing firms such as auto manufacturing plants and steel companies (Datta et al., 2005; Gant, Ichniowski, \& Shaw, 2002; Ichniowski \& Shaw, 1999; Macduffie, 1995), and some general service firms such as banks (Delery \& Doty, 1996; Richard \& Johnson, 2001) and call centers (Batt, 2002), a mixture of manufacturing firms, general service firms (Guthrie et al., 2009; Huselid, 1995), or high technology firms (Subramaniam \& Youndt, 2005). The important context of professional service firms has largely been omitted except in two recent articles by McClean and Collins (2011) in their study of small medical and legal offices and by Fu et al. (2013) in their study of HPWS in accounting firms. Based on the trends in PSFs research, there has been a serious lack of attention given to systematic HRM. Some topics that have been addressed in existing research include organizational structure (Cooper, Hinings, Greenwood, \& Brown, 1996; Greenwood et al., 
1990; Pinnington \& Morris, 2003), tournament promotion systems (Morris \& Pinnington, 1998) and knowledge management (Alvesson, 2001; Donaldson, 2001; Empson, 2001; Løwendahl, Revang, \& Fosstenlokken, 2001; Morris, 2001; Suddaby \& Greenwood, 2005; Willman, O'Creevy, Nicholson, \& Soane, 2001). However, research on the HPWS in PSFs is scarce. This study addresses the above two gaps by analyzing how HPWS operate in professional service firms.

\section{Implications for Managers}

Several important lessons for practitioners can be drawn from our discussion of the practicesresources-uses-performance linkage approach.

First, firms with extensive utilization of HPWS will experience increases in firm performance. This indicates the importance of HR systems to managers. Unfortunately, investing in an HRM system can generate high cost for firms, especially in this economic crisis. A lot of firms may think of reducing training hours and freezing promotion systems. However, HPWS will help firms to achieve higher performance in the long run. Managers in PSFs need to think about how to improve HPWS efficiency and effectiveness without increasing the cost base. For example, one consulting firm has adopted online training instead of sending employees outside of the company for training. This simultaneously ensures that the employees received the required training while reducing the cost.

This study also provides managers in PSFs with information on the underlying mechanisms through which HPWS operate to improve firm performance. Three resources were identified as the human, social and organizational capital. The HR practices help the firm to create these capital resources. The managers can analyze the need for any particular resource and then takes action to build it up. For example, if they perceive that the human capital needs to be improved immediately, the managers need to focus on the human capital enhancing HR practices, such as training and development. If organizational systems and processes prevent knowledge flow within departments, managers may need to consider redesigning the system or improving communication channels.

In addition, this study proposed the uses of resources as the second set of mediators between HPWS and firm performance. It suggested that merely having resources is insufficient for success. Only when these resources are utilized effectively can firms achieve high performance. Four means were identified to utilize human, social, and organizational capital to help firms efficiently exploit, transform and explore knowledge. These were: sensing market changes, team formation and utilization, leveraging knowledge from seniors to juniors (shortened to leveraging knowledge), as well as combining and exchanging knowledge. The importance of both resources and the uses of these resources requires managers in PSF to promote the HR systems that create resources and also that enhance the uses mechanism. For example, managers need to pay more attention to these four means to use their resources. They can then check whether their HR systems are playing the correct role in facilitating them. If they find that the firms need to leverage more knowledge from seniors to juniors, they may need to enhance mentoring systems in the HPWS.

Furthermore, this study provides some decision-making support for managers in PSFs by identifying resources and resource use effectiveness. For example, when managers know that their external social capital is high, they may exploit it to win new business through a focused exploration strategy. This study highlights how managers improve the pool of human, social, and organizational capital through HPWS, such as training and development, participation, and so forth. It also demonstrates how to explore, transform, and exploit these resources to create new services and to attract new clients through four means. These four means were identified as follows: sensing market changes, team formation and utilization, leveraging knowledge (i.e., leveraging tacit knowledge from seniors to juniors), and combining and exchanging knowledge. These four means were defined as the uses capabilities for PSFs.

\section{Conclusion}

The purpose of this study was to investigate the indirect impact of HPWS on firm performance in the professional service context. The practices-resource-uses-performance framework formed in this 
paper has addressed the question of how HPWS can affect firm performance in PSFs. HPWS affect firm performance through two steps: (1) improving the firms' resources of human, social, and organizational capital; and (2) through the effective uses of these resources. Four means were identified to achieve exploration, transformation, and exploitation of resources. They were: sensing market changes, team formation and utilization, leveraging knowledge from seniors to juniors, as well as combining and exchanging knowledge. Future research could be focused in two directions. First, the new approach of "HR practices-resources-uses-performance" model requires empirical support by collecting data. Second, research on how to achieve the balance of exploration, transformation, and exploitation necessitates further empirical enquiry.

\section{References}

Alvesson, M. (2001). Knowledge work: Ambiguity, image and identity. Human Relations, 54, 863-886. doi:10.1177/0018726701547004

Anand, N., Gardner, H. K., \& Morris, T. (2007). Knowledge-based innovation: Emergence and embedding of new practice areas in management consulting firms. Academy of Management Journal, 50, 406-428. doi:10.5465/AMJ.2007.24634457

Arthur, J. B. (1994). Effects of human resource systems on manufacturing performance and turnover. Academy of Management Journal, 37, 670-687. doi:10.2307/256705

Barney, J. (1991). The resource-based model of the firm: Origins, implications, and prospects. Journal of Management, 17, 97-98. doi:10.1177/014920639101700107

Barney, J. B., \& Arikan, A. M. (2001). The resource-based view: Origins and implications. In M. A. Hitt, R. E. Freeman, \& J. S. Harrison (Eds.), The Blackwell handbook of strategic management (pp. 124-188). Oxford, United Kingdom: Blackwell.

Batt, R. (2002). Managing customer services: Human resource practices, quit rates, and sales growth. Academy of Management Journal, 45, 587-597. doi:10.2307/3069383

Becker, B. E., \& Huselid, M. A. (1998). High performance work systems and firm performance: A synthesis of research and managerial implications. Research in Personnel and Human Resources Management, 16, 53-102.

Becker, G. (1964). Human capital: A theoretical and empirical analysis, with special reference to education. Chicago, IL: University of Chicago Press.

Bourdieu, P. (1985). The social space and the genesis of groups. Theory and Society, 14, 723-744. doi:10.1007/ BF00174048

Bowen, D. E., \& Ostroff, C. (2004). Understanding HRM-firm performance linkages: The role of the "strength" of the HRM system. The Academy of Management Review, 29, 203-221.

Burt, R. S. (1992). Structural holes. Cambridge, United Kingdom: Cambridge University Press.

Chuang, C., Chen, S., \& Chuang, C. (2013). Human resource management practices and organizational social capital: The role of industrial characteristics. Journal of Business Research, 66, 678-687. doi:10.1016/ j.jbusres.2012.04.002

Coleman, J. S. (1988). Social capital in the creation of human capital. American Journal of Sociology, 94, S95-S120. doi:10.1086/228943

Collins, C. J., \& Clark, K. D. (2003). Strategic human resource practices, top management team social networks, and firm performance: The role of human resource practices in creating organizational competitive advantage. Academy of Management Journal, 46, 740-751. doi:10.2307/30040665

Collins, C. J., \& Smith, K. G. (2006). Knowledge exchange and combination: The role of human resource practices in the performance of high-technology firms. Academy of Management Journal, 49, 544-560. doi:10.5465/AMJ.2006.21794671

Combs, J., Liu, Y., Hall, A., \& Ketchen, D. (2006). How much do high-performance work practices matter? A meta-analysis of their effects on organizational performance. Personnel Psychology, 59, 501-528. doi: 10.1111/j.1744-6570.2006.00045.x

Cooper, D. J., Hinings, B., Greenwood, R., \& Brown, J. L. (1996). Sedimentation and transformation in organizational change: The case of Canadian law firms. Organization Studies, 17, 623-647. doi:10.1177/ 017084069601700404

Daft, R. L., \& Weick, K. E. (1984). Toward a model of organizations as interpretation systems. The Academy of Management Review, 9, 284-295.

Datta, D. K., Guthrie, J. P., \& Wright, P. M. (2005). Human resource management and labor productivity: Does industry matter. Academy of Management Journal, 48, 135-145. doi:10.5465/AMJ.2005.15993158 
Delery, J. E., \& Doty, D. H. (1996). Modes of theorizing in strategic human resource management: Tests of universalistic, contingency, and configurational performance predictions. Academy of Management Journal, 39, 802-835. doi:10.2307/256713

Delery, J. E., \& Shaw, J. D. (2001). The strategic management of people in work organizations: Review, synthesis, and extension. In K. M. Rowland \& G. R. Ferris (Eds.), Research in personnel and human resources management (pp. 165-197). Greenwich, CT: JAI Press.

Donaldson, L. (2001). Reflections on knowledge and knowledge intensive firms. Human Relations, 54, 955-963. doi:10.1177/0018726701547008

Empson, L. (2001). Fear of exploitation and fear of contamination: Impediments to knowledge transfer in mergers between professional service firms. Human Relations, 54, 839-862. doi:10.1177/ 0018726701547003

Empson, L. (2007). Managing the modern law firm: New challenges, new perspectives. Cary, NC: Oxford University Press.

Evans, W. R., \& Davis, W. D. (2005). High-performance work systems and organizational performance: The mediating role of internal social structure. Journal of Management, 31, 758-775. doi:10.1177/ 0149206305279370

Ferris, G. R., Arthur, M. M., Berkson, H. M., Kaplan, D. M., Harrell-Cook, G., \& Frink, D. D. (1998). Toward a social context theory of the human resource management-organization effectiveness relationship. Human Resource Management Review, 8, 235-264. doi:10.1016/S1053-4822(98)90004-3

Freidson, E. (1986). Professional powers: A study of the institutionalization of formal knowledge. Chicago, IL: University of Chicago Press.

Fu, N., Flood, P. C., Bosak, J., Morris, T., \& O’Regan, P. (2013). Exploring the performance effect of high performance work system on service supply chain in professional service firms. Supply Chain Management: An International Journal, 18, 292-307. doi:10.1108/SCM-04-2012-0118

Gant, J., Ichniowski, C., \& Shaw, K. (2002). Social capital and organizational change in high-involvement and traditional work organizations. Journal of Economics and Management Strategy, 11, 289-328. doi:10.1162/ 105864002317474576

Gittell, J. H., Seidner, R., \& Wimbush, J. (2010). A relational model of how high-performance work systems work. Organization Science, 21, 490-506. doi:10.1287/orsc.1090.0446

Grant, R. M. (1996a). Prospering in dynamically-competitive environments: Organizational capability as knowledge integration. Organization Science, 7, 375-387. doi:10.1287/orsc.7.4.375

Grant, R. M. (1996b). Toward a knowledge-based theory of the firm. Strategic Management Journal, 17, $109-122$

Greenwood, R., Deephouse, D. L., \& Li, S. X. (2007). Ownership and performance of professional service firms. Organization Studies, 28, 219-238. doi:10.1177/0170840606067992

Greenwood, R., Hinings, C. R., \& Brown, J. (1990). "P 2-Form" strategic management: Corporate practices in professional partnerships. Academy of Management Journal, 33, 725-755. doi:10.2307/256288

Greenwood, R., Li, S. X., Prakash, R., \& Deephouse, D. L. (2005). Reputation, diversification, and organizational explanations of performance in professional service firms. Organization Science, 16, 661-673. doi:10.1287/orsc. 1050.0159

Guest, D. E. (1997). Human resource management and performance: A review and research agenda. International Journal of Human Resource Management, 8, 263-276. doi:10.1080/095851997341630

Guthrie, J. P. (2001). High-involvement work practices, turnover, and productivity: Evidence from New Zealand. Academy of Management Journal, 44, 180-190. doi:10.2307/3069345

Guthrie, J., Flood, P., Liu, W., \& MacCurtain, S. (2009). High performance work systems in Ireland: Human resource and organizational outcomes. The International Journal of Human Resource Management, 20, 112-125. doi:10.1080/09585190802528433

Hansen, M. T., Nohria, N., \& Tierney, T. (1999). What's your strategy for managing knowledge? Harvard Business Review, 77, 106-116.

Hitt, M. A., Bierman, L., Shimizu, K., \& Kochhar, R. (2001). Direct and moderating effects of human capital on strategy and performance in professional service firms: A resource-based perspective. Academy of Management Journal, 44, 13-28. doi:10.2307/3069334

Hitt, M. A., Shimizu, K., Uhlenbruck, K., \& Bierman, L. (2006). The importance of resources in the internationalization of professional service firms: The good, the bad, and the ugly. Academy of Management Journal, 49, 1137-1157. doi:10.5465/AMJ.2006.23478217

HM Treasury. (2009). Professional Services Global Competitiveness Group report March 2009. London, United Kingdom: Royal Institution of Chartered Surveyors. Retrieved from http://www.rics.org/site/scripts/ download_info.aspx?downloadID $=3255$ 
Hogan, S. J., McColl-Kennedy, J. R., Soutar, G. N., \& Sweeney, J. C. (2008, December). Beyond the manufacturing mindset: Development of the professional service firm innovation (PSFI) scale. Presented at the Australia and New Zealand Marketing Academy Conference, Australia and New Zealand Marketing Academy, Sydney, NSW.

Huselid, M. A. (1995). The impact of human resource management practices on turnover, productivity, and corporate financial performance. Academy of Management Journal, 38, 635-672. doi:10.2307/256741

Ichniowski, C., \& Shaw, K. (1999). The effects of human resource management systems on economic performance: An international comparison of U.S. and Japanese plants. Management Science, 45, 704-721. doi: $10.1287 / \mathrm{mnsc} .45 .5 .704$

Ireland, R. D., Hitt, M. A., \& Sirmon, d. G. (2003). A model of strategic entrepreneurship: The construct and its dimensions. Journal of Management, 29, 963-989.

Jiang, K., Lepak, D. P., Hu, J., \& Baer, J. C. (2012). How does human resource management influence organizational outcomes? A meta-analytic investigation of mediating mechanisms. Academy of Management Journal, 55, 1264-1294. doi:10.5465/amj.2011.0088

Kang, S. C., \& Snell, S. A. (2009). Intellectual capital architectures and ambidextrous learning: A framework for human resource management. Journal of Management Studies, 46, 65-92. doi:10.1111/j.14676486.2008.00776.x

Kopelman, R. E., Brief, A. P., \& Guzzo, R. A. (2005). The role of climate and culture in productivity. In B. Schneider (Ed.) Organizational climate and culture (pp. 282-318). San Francisco, CA: Jossey-Bass.

Leana, C. R., \& Van Buren III, H. J. (1999). Organizational social capital and employment practices. Academy of Management Review, 24, 538-555.

Lichtenthaler, U. (2009). Absorptive capacity, environmental turbulence, and the complementarity of organizational learning processes. Academy of Management Journal, 52, 822-846. doi:10.5465/ AMJ.2009.43670902

Lin, N. (2001). Building a network theory of social capital. In N. Lin, K. Cook, \& R. S. Burt (Eds.), Social capital: Theory and research (pp. 3-29). New Brunswick, NJ: Aldine Transaction.

Løwendahl, B. R. (2000). Strategic management of professional service firms (2nd ed.). Copenhagen, Denmark: Handelshojskolens Forlag.

Løwendahl, B. R., Revang, O., \& Fosstenlokken, S. M. (2001). Knowledge and value creation in professional service firms: A framework for analysis. Human Relations, 54, 911-931. doi:10.1177/0018726701547006

Macduffie, J. P. (1995). Human resource bundles and manufacturing performance: Organizational logic and flexible production systems in the world auto industry. Industrial \& Labor Relations Review, 48, 197-221. doi: $10.2307 / 2524483$

Maister, D. H. (1993). Managing the professional service firm. New York, NY: Free Press.

March, J. G. (1991). Exploration and exploitation in organizational learning. Organization science, 2, 71-87. doi:10.1287/orsc. 2.1 .71

McClean, E., \& Collins, C. J. (2011). High-commitment HR practices, employee effort, and firm performance: Investigating the effects of HR practices across employee groups within professional services firms. Human Resource Management, 50, 341-363. doi:10.1002/hrm.20429

Moore, K., \& Birkinshaw, J. (1998). Managing knowledge in global service firms: Centers of excellence. The Academy of Management Executive, 12, 81-92.

Morris, S. S., \& Snell, S. A. (2008, September). The value of knowledge for professional service workers: A use value perspective. Presented at the conference on HRM and Knowledge Related Performance, Copenhagen, Denmark.

Morris, T. (2001). Asserting property rights: Knowledge codification in the professional service firm. Human Relations, 54, 819-838. doi:10.1177/0018726701547002

Morris, T., \& Empson, L. (1998). Organisation and expertise: An exploration of knowledge bases and the management of accounting and consulting firms. Accounting, Organizations and Society, 23(5-6), 609-624. doi:10.1016/S0361-3682(98)00032-4

Morris, T., Gardner, H. K., \& Anand, N. (2007, July). Its not what we do its how we do it: Private equity's impact on professional advisors. Presented at the Clifford Chance Conference on Professional Service Firms, University of Illinois, Chicago.

Nachum, L. (1999). Measurement of productivity of professional services: An illustration on Swedish management consulting firms. International Journal of Operations \& Production Management, 19, 922-950. doi:10.1108/01443579910280269

Nahapiet, J., \& Ghoshal, S. (1998). Social capital, intellectual capital, and the organizational advantage. Academy of Management Review, 23, 242-266.

Newell, S., Tansley, C., \& Huang, J. (2004). Social capital and knowledge integration in an ERP Project Team: 
The importance of bridging and bonding. British Journal of Management, 15 (Suppl. 1) 43-57. doi:10.1111/ j.1467-8551.2004.00405.x

O’Sullivan, A., \& Sheffrin, S. M. (1998). Economics: Principles and tools. Upper Saddle River, NJ: Prentice Hall.

Paauwe, J., Guest, D. E., \& Wright, P. M. (2013). HRM and performance: Achievements and challenges. West Sussex/UK: Wiley.

Pennings, J. M., Lee, K., \& Van Witteloostuijn, A. (1998). Human capital, social capital, and firm dissolution. Academy of Management Journal, 41, 425-440. doi:10.2307/257082

Penrose, E. G. (1959). The theory of the growth of the firm. New York, NY: Wiley.

Pfeffer, J. (1998). The human equation: Building profits by putting people first (1st ed.). Boston, MA: Harvard Business Press.

Phillips, D. J. (2001). The promotion paradox: Organizational mortality and employee promotion chances in Silicon Valley law firms, 1946-1996. American Journal of Sociology, 106, 1058-1098. doi:10.1086/320293

Pinnington, A., \& Morris, T. (2003). Archetype change in professional organizations: Survey evidence from large law firms. British Journal of Management, 14, 85-99. doi:10.1111/1467-8551.00267

Putnam, R. D. (1993). Making democracy work: Civic traditions in modern Italy. Princeton, NJ: Princeton University Press.

Richard, O. C., \& Johnson, N. B. (2001). Strategic human resource management effectiveness and firm performance. The International Journal of Human Resource Management, 12, 299-310.

Robertson, M., Scarbrough, H., \& Swan, J. (2003). Knowledge creation in professional service firms: Institutional effects. Organization Studies, 24, 831-857. doi:10.1177/0170840603024006002

Schultz, T. W. (1961). Investment in human capital. The American Economic Review, 51, 1-17.

Sirmon, D. G., Hitt, M. A., \& Ireland, R. D. (2007). Managing firm resources in dynamic environments to create value: Looking inside the black box. The Academy of Management Review, 32, 273-292. doi:10.5465/ AMR.2007.23466005

Snell, S. A., \& Dean Jr., J. W. (1992). Integrated manufacturing and human resource management: A human capital perspective. Academy of Management Journal, 35, 467-504. doi:10.2307/256484

Starbuck, W. H. (1992). Learning by knowledge-intensive firms. Journal of Management Studies, 29, 713-740. doi:10.1111/j.1467-6486.1992.tb00686.x

Stumpf, S. A., Doh, J. P., \& Clark, K. D. (2002). Professional services firms in transition: Challenges and opportunities for improving performance. Organizational Dynamics, 31, 259-279. doi:10.1016/S00902616(02)00113-4

Subramaniam, M., \& Youndt, M. A. (2005). The influence of intellectual capital on the types of innovative capabilities. Academy of Management Journal, 48, 450-463. doi:10.5465/AMJ.2005.17407911

Subramony, M. (2009). A meta-analytic investigation of the relationship between HRM bundles and firm performance. Human Resource Management, 48, 745-768. doi:10.1002/hrm.20315

Suddaby, R., \& Greenwood, R. (2005). Rhetorical strategies of legitimacy. Administrative Science Quarterly, 50, 35-67.

Takeuchi, R., Lepak, D. P., Wang, H. C., \& Takeuchi, K. (2007). An empirical examination of the mechanisms mediating between high-performance work systems and the performance of Japanese organizations. Journal of Applied Psychology, 92, 1069-1083. doi:10.1037/0021-9010.92.4.1069

Teece, D. J. (2000). Strategies for managing knowledge assets: The role of firm structure and industrial context. Long Range Planning: International Journal of Strategic Management, 33, 35-54. doi:10.1016/S00246301(99)00117-X

Teece, D. J., Pisano, G., \& Shuen, A. (1997). Dynamic capabilities and strategic management. Strategic Management Journal, 18, 509-533. doi:10.1002/(SICI)1097-0266(199708)18:7<509::AIDSMJ882>3.0.CO;2-Z

Truss, C., \& Gill, J. (2009). Managing the HR function: The role of social capital, Personnel Review, 38, 674-695. doi:10.1108/00483480910992274

Von Nordenflycht, A. (2007). Is public ownership bad for professional service firms? Ad agency ownership, performance, and creativity. Academy of Management Journal, 50, 429-445. doi:10.5465/ AMJ.2007.24634774

Von Nordenflycht, A. (2010). What is a professional service firm? Toward a theory and taxonomy of knowledge intensive firms. The Academy of Management Review, 35, 155-174. doi:10.5465/AMR.2010.45577926

Wasko, M. M., Faraj, S. (2005). Why should I share? Examining social capital and knowledge contribution in electronic networks of practice. MIS Quarterly, 29, 35-57.

Wernerfelt, B. (1984). A resource-based view of the firm. Strategic Management Journal, 5, 171-180. doi:10.1002/smj.4250050207 
Willman, P., O'Creevy, M. P. F., Nicholson, N., \& Soane, E. (2001). Knowing the risks: Theory and practice in financial market trading. Human Relations, 54, 887-910. doi:10.1177/0018726701547005

Wright, P. M., Dunford, B. B., \& Snell, S. A. (2001). Human resources and the resource based view of the firm. Journal of Management, 27, 701-721. doi:10.1177/014920630102700607

Wright, P. M., \& Gardner, T. M. (2000). Theoretical and empirical challenges in studying the HR practices-firm performance relationship (Working Paper No. 00-04). Ithaca, NY: Cornell University School of Industrial and Labor Relations.

Wright, P. M., \& McMahan, G. C. (2011). Exploring human capital: Putting "human" back into strategic human resource management. Human Resource Management Journal, 21, 93-104. doi:10.1111/j.17488583.2010.00165.x

Youndt, M. A., Snell, S. A., Dean Jr., J. W., \& Lepak, D. P. (1996). Human resource management, manufacturing strategy, and firm performance. Academy of Management Journal, 39, 836-866. doi:10.2307/256714

Youndt, M. A., Subramaniam, M., \& Snell, S. A. (2004). Intellectual capital profiles: An examination of investments and returns. Journal of Management Studies, 41, 335-361. doi:10.1111/j.14676486.2004.00435.x

Received April 16, 2013

Latest revision received July 23, 2013

Accepted August 1, 2013 